\title{
Statyba
}

\section{THE INFLUENCE OF NATURAL HUMIDITY UPON THE INDEX OF THE COMPRESSION OF LIMNOGLACIAL CLAY}

\section{A. Alikonis}

To cite this article: A. Alikonis (2001) THE INFLUENCE OF NATURAL HUMIDITY UPON THE INDEX OF THE COMPRESSION OF LIMNOGLACIAL CLAY, Statyba, 7:1, 34-37, DOI: 10.1080/13921525.2001.10531696

To link to this article: https://doi.org/10.1080/13921525.2001.10531696

曲 Published online: 30 Jul 2012.

Submit your article to this journal $₫$

Џ Article views: 55

4 Citing articles: 1 View citing articles 준 


\section{NATŪRALIOJO DRĖGNIO İTAKA LIMNOGLACIALINIO MOLIO KOMPRESIJOS KOEFICIENTUI}

\section{A. Alikonis}

Vilniaus Gedimino technikos universitetas

\section{Ivadas}

Smèlinių ir molingujų gruntų spũdumas labai skiriasi, be to, spūdumas priklauso nuo daugelio kitụ sąlygu, tokiụ kaip tankumas, formavimosi sąlygos, natūraliomis slūgsojimo sąlygomis veikusios apkrovos ir kt.

Grunto poringumo ir spūdumo koeficientai nèra vieninteliai rodikliai, rodantys apkrovos ir spūdumo ryši Labai dažnai manoma, kad yra svarbu poringumo koeficiento priklausomybę nuo apkrovos išreikšti matematine formule.

Grunto spüdumą charakterizuoja kompresinès kreivès nuolydis $\mathfrak{i}$ abscisių aši iprastinejje koordinačių sistemoje.

Eksperimentų rezultatus pateikdami tokia forma skirtingiems kompresinès kreivès tarpams gauname skirtingas matematines poringumo koeficiento priklausomybès nuo apkrovos išraiškas. Pavyzdžiui, vienokia šios priklausomybès matematinè išraiška bus kompresinès kreivès pradžioje, kitokia viduryje ar jos tęsinyje. Kompresinès kreivès atskirų vietų nuolydžio i abscisių aši kampo tangentas iprastinèje koordinačių sistemoje vadinamas spūdumo koeficientu ir išreiškiamas formule:

$$
m_{V}=\frac{e_{1}-e_{2}}{\sigma_{2}-\sigma_{1}}
$$

$e_{1}$ ir $e_{2}$ - poringumo koeficientai intervalo pradžioje ir pabaigoje; $\sigma_{1}, \sigma_{2}$ - itempimai intervalo pradžioje ir pabaigoje.

Spūdumo koeficientas daugeliu atvejų yra nepatogus taikyti.

Grunto kompresinė kreivẻ pusiau logaritminèje koordinačių sistemoje yra tiesé, todèl jos nuolydžio i abscisiu aši kampo tangentas bus pastovusis dydis. Jis yra laikomas grunto kompresijos koeficientu, gali būti taikomas dideliu apkrovų kaitos intervalu ir yra skirtingas ne tik ivairiems grunto tipams, bet ir tam pačiam gruntui, pavyzdžiui, moliui priklausomai nuo jo būvio rodikliụ, mineralinès sudèties ir formavimosi ypatumų.

\section{Kompresijos koefíciento teorinès prielaidos}

Molingojo grunto kompresinis grafikas pusiau logaritminejje koordinačiụ sistemoje turi dvi skirtingas dalis - vieną su mažesniu nuolydžiu, kitą - su didesniu nuolydžiu. Grafiko $e=f(\lg \sigma)$ nuolydžiu kaitos vieta (1 pav.) yra artima grunto struktūriniam stiprumui, reliktiniam ir geostatiniam slègiui.

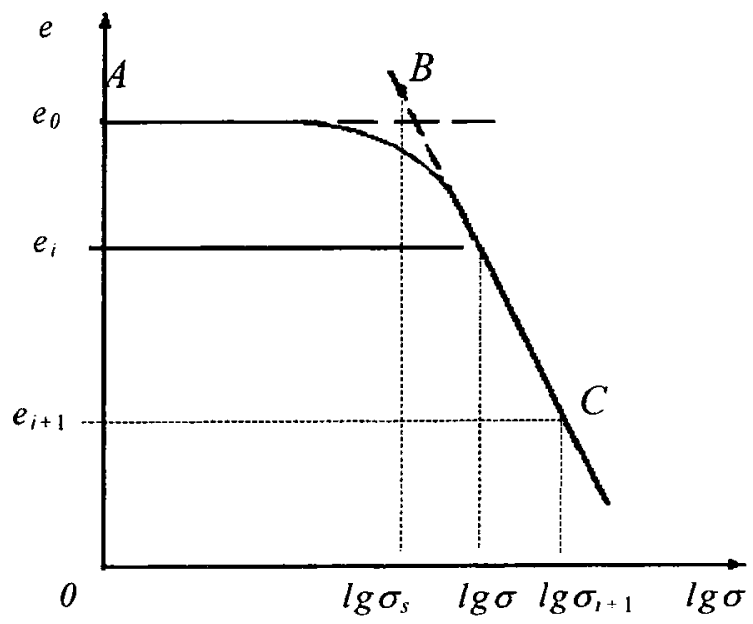

1 pav. Molingojo grunto kompresijos grafikas pusiau logaritminèje koordinačiu sistemoje

Fig 1. Compression curve of clay in semi-logarithmic scale

Pagal reliktinio slègio, kuris artimas grunto struktūriniam stiprumui, ir geostatinio slègio santyki nustatomas grunto konsolidacijos rodiklis [1] ir sprendžiama, ar gruntas natūraliomis slūgsojimo sąlygomis normaliai konsoliduotas, ar perkonsoliduotas. 
Grunto kompresijos koeficientas $C_{c}$ nustatomas antrajai grafiko daliai ir apskaičiuojamas pagal formulę:

$$
C_{c}=\frac{e_{i}-e_{i+1}}{\lg \sigma_{i+1}-\lg \sigma_{i}},
$$

$e_{i}$ ir $e_{i+1}$ - poringumo koeficientai skaičiuojamojo intervalo pradžioje ir pabaigoje; $\lg \sigma_{i}, \lg \sigma_{i+1}$ - itempimai to paties intervalo pradžioje ir pabaigoje.

Labai dažnai skaičiuojant kompresijos koeficientą intervalo pradžia laikoma grunto reliktinis slègis, prilygstantis grunto struktūriniam stiprumui [2, 3]. Kompresijos koeficientas taikomas grunto sluoksnio deformacijoms $S_{c}$ apskaičiuoti:

$$
S_{c}=\frac{C_{c} \cdot \lg \left(\frac{\sigma_{1}^{\prime}}{\sigma_{0}^{\prime}}\right)}{1+e_{0}} H,
$$

$C_{c}$ - grunto kompresijos koeficientas; $\sigma_{1}^{\prime}$ - itempimai grunte skaičiuojamojo intervalo pabaigoje arba jtempimai nuo gruntui perduotos apkrovos; $\sigma_{0}^{\prime}-$ itempimai nuo reliktinio slègio; $e_{0}-$ pradinis poringumo koeficientas; $H$ - grunto sluoksnio storis.

Kompresijos koeficientas yra taikomas praktiškai (2), todèl yra pateikiamas kaip viena iš grunto savybių, apibūdinančių jo spūdumą [4]. Kompresijos koeficiento skaitinè reikšmè yra skirtinga ne tik ivairiems grunto tipams, bet ir tam pačiam gruntui priklausomai nuo jo būvio ir savybių [5], natūraliojo drégnio, poringumo ir kt.

\section{Tyrimu metodika ir gruntai}

Kompresijos koeficiento priklausomybei nuo grunto natūraliojo drègnio nustatyti tirtas Lietuvos limnoglacialinis gruntas kompresiniuose aparatuose, nustatytos jo geotechninès savybès. Kompresiniai bandymai atlikti pamažu didinant apkrovą iki geostatiniụ itempių. Taip buvo užfiksuotas itempis, atitinkantis grunto struktūrini stiprumą [6]. Ji nustatyti reikia tam, kad būtų galima apskaičiuoti kompresijos koeficientą $C_{c}$, kuris charakterizuoja grunto spūdumą, kai apkrovos didesnès už struktūrini stiprumą.

Grunto natūralusis drègnis nustatytas pagal standartinę metodika, t. y. kaip vandens masès, išgarinamos gruntą džiovinant nuo $100^{\circ} \mathrm{C}$ iki $105^{\circ} \mathrm{C}$ temperatūroje iki pastovios masès, ir kietuju daleliụ masès santykis procentais.
Tyrimams naudotas Lietuvos limnoglacialinis molis. Pavyzdžiai imti iš pagrindinių limnoglacialinių baseinų: Jūros-Šešupès, Kauno-Kaišiadorių, Mūšos ir Dysnos. Pavyzdžiu èmimo gylis - nuo $1,5 \mathrm{~m}$ iki $6 \mathrm{~m}$. Tyrimams atrinkti gruntai, turintys mikrojuostuotą struktūra. Tirti moliai, kurių plastiškumo rodiklis 17 ir didesnis, prisodrinti vandens - soties rodiklis $0,8-1$. Tirti limnoglacialiniai moliai daugiausia buvo sudaryti iš molio sluoksnelių, todèl juose, kaip rodo kitụ autoriụ [7] atlikti tyrimai, dominavo molio dalelès $(<0,005 \mathrm{~mm})$. Mineralinę limnoglacialinio grunto sudeti sudaro hidrožèrutis (vidutiniškai nuo 65\% iki 75\%), koalinitas (vidutiniškai $0-10 \%$ ) ir chlorito (vidutiniškai $0-10 \%$ ) priemaiša [7]. Didžiausias koalinito kiekis (nuo 10\% iki $30 \%$ ) nustatytas Dysnos ir Mūšos limnoglacialiniụ baseinų nuosèdose [7].

\section{Tyrimo rezultatai}

Apdorojant spūdumo tyrimo kompresiniuose aparatuose (odometruose) rezultatus apskaičiuoti poringumo koeficientai esant ivairioms apkrovoms.

Pagal poringumo koeficiento priklausomybes nuo itempimų, viršijančių grunto struktūrini stiprumą, apskaičiuoti kompresijos koeficientai (2). Dažniausiai skaičiavimo intervalas buvo tarp itempimų $\sigma=0,2 \mathrm{MPa}$ ir $\sigma=0,4 \mathrm{MPa}$, kurie kaip tik atiteko tiesiajai poringumo koeficiento priklausomybès nuo itempių grafiko pusiau logaritminèje koordinačiụ sistemoje daliai. Apskaičiuoti kompresijos koeficientai $C_{c}$ yra susieti su to grunto natūraliuoju drègniu $W$.

Grunto drègnis rodo ir kitas jo savybes, nuo kuriụ iš dalies priklauso spūdumo rodikliai. Kai kurie iš jų, tokie kaip grunto tankio ir sauso grunto tankio ryšys su drègniu, išryškejja analizuojant grunto vieno kubinio centimetro drègnị:

$$
W=\frac{\rho-\rho_{d}}{\rho_{d}},
$$

$W$ - grunto drégnis; $\rho$ - grunto tankis; $\rho_{d}-$ sauso grunto tankis.

Iš (4) formulès galima gauti sauso grunto tankio priklausomybę nuo natūraliojo tankio ir drègnio:

$$
\rho_{d}=\frac{\rho}{1+W}
$$

Kai grunto drègnis išreiškiamas procentais, (5) formule yra tokia: 


$$
\rho_{d}=\frac{\rho}{1+\frac{W}{100}}
$$

Grunto drègnis, natūralusis tankis, sauso grunto tankis ir grunto dalelių tankis, kuris praktiniams skaičiavimams imamas kaip pastovusis dydis tam tikriems grunto tipams, yra susieti su grunto poringumu $n$ :

$$
n=1-\frac{\rho_{d}}{\rho_{s}}
$$

(7) formulè yra nepatogi skaičiuojant grunto tūrio kaitą pasikeitus poringumui, todèl poringumas, kaip grunto geotechninių savybiụ rodiklis, dažnai išreiškiamas poringumo koeficientu:

$$
e=\frac{\rho_{s}-\rho_{d}}{\rho_{s}},
$$

$e$ - poringumo koeficientas; $\rho_{s}-$ grunto daleliụ tankis; $\rho_{d}$ - sauso grunto tankis.

Formuliu (4-8) analizè rodo, kad grunto poringumo koeficiento kaitos nuo apkrovos priklausomybę geriausia susieti su drègniu, kuris kartu su kitomis geotechninių savybiụ reikšmèmis rodo grunto tūrio pokyčius, taikomas nustatant takumo rodikli, t. y. kartu ir grunto konsistencija.

Pagal drègni ir kompresijos koeficientą buvo apskaičiuotas koeficientas $k$, kuris rodo kompresijos koeficiento santyki $C_{c}$ su natūraliuoju drègniu $W$ (2 pav.).

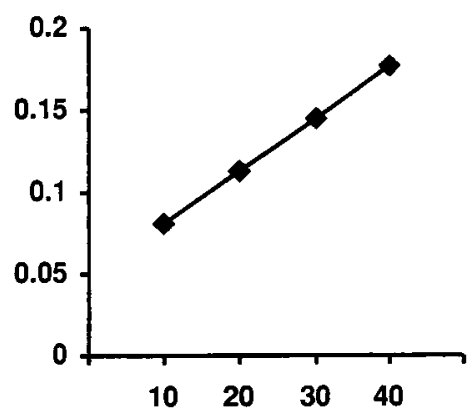

2 pav. Kompresijos koeficiento $C_{c}$ priklausomybès nuo natūraliojo drègnio $W$ grafikas

Fig 2. Dependence of the coefficient of compressibility $C_{c}$ upon natural humidity $W$

Iš 33 bandymų rezultatų apskaičiuota vidutinè koeficiento $\mathrm{k}$ reikšmė yra 0,00486 . Tyrimo rezultatus apdorojus matematiškai gauta formulè kompresijos koeficientui apskaičiuoti:

$$
C_{c}=0,0032 W+0,049,
$$

$C_{c}$ - kompresijos koeficientas; $W$ - natūralusis limnoglacialinio molio drègnis, \%.

Tirto grunto natūraliojo drégnio $\mathrm{W}$ reikšmès kito nuo $18 \%$ iki $39 \%$, apskaičiuotos kompresijos koeficiento $C_{c}$ reikšmès kito nuo 0,13 iki 0,24 , o koeficiento $k$ reikšmès - nuo 0,0033 iki 0,0066 .

Grunto kompresijos koeficiento susiejimas su takumo drègniu, ką yra darę ir kiti autoriai (A. W. Skemptonas, $1944 \mathrm{~m}$.), kelia daug abejonių, nes takumo drègnis daugiau priklauso nuo molinių dalelių kiekio grunte ir neatspindi natūraliojo grunto būvio. Autorius, atlikęs kompresijos koeficiento skaičiavimus pagal jo priklausomybę nuo takumo drègnio ir priklausomybę nuo natūraliojo drègnio, gavo skirtingus rezultatus. Tai rodo, kad grunto kompresijos koeficientas, gautas skaičiuojant jo proklausomybę nuo takumo drégnio, neatspindi natūralaus grunto spūdumo priklausomybès nuo apkrovos. Kompresijos koeficiento priklausomybè nuo drègnio yra pagrista ir tuo, kad drègnis ir jo kaita rodo natūraliojo grunto būvị ir kad vandens prisodrinto grunto poringumo koeficientas, kurio priklausomybès nuo apkrovos grafikas taikomas kompresijos koeficientui apskaičiuoti, yra susietas su grunto drègniu.

\section{Išvados}

1. Kompresijos koeficiento reikšmė priklauso nuo grunto būvio, mineralinès sudèties ir formavimosi sąlygụ.

2. Kompresijos koeficientas, apskaičiuotas pagal poringumo koeficiento priklausomybès nuo apkrovos grafiką pusiau logaritminejje koordinačių sistemoje, yra pastovusis dydis ir gali būti taikomas grunto sluoksnio deformacijoms apskaičiuoti dideliu apkrovų intervalu.

3. Tirto limnoglacialinio molio kompresijos koeficientas kito nuo 0,13 iki 0,24 priklausomai nuo natūraliojo drègnio, kuris buvo nuo $18 \%$ iki $39 \%$.

4. Kompresijos koeficientas, apskaičiuotas pagal (9) formulę, gali būti taikomas prognozuojant grunto sluoksnio deformacijas nuo apkrovos poveikio.

\section{Literatūra}

1. Lietuvos standartas. LST 1445. Geotechnika. Grunty klasifikacija ir identifikacija / Lietuvos standartizacijos departamentas, 1996. $21 \mathrm{p}$. 
2. R. F. Craig. Soil Mechanics. E. FN SPON London and New York, 1997. 485 p.

3. M. I. Tomlinson, R. Boorman. Foundation Design and construction. ELBS. Singapore, 1994. 842 p.

4. A. F. Lhyde. Post-cyclic shear strength of silty clay. Proceedings of the eleventh international conference on soil mechanics and foundation engineering. San Francisco, 1985, p. 2682-2683.

5. Karl Terzaghi, Ralph B., Peck, Giholamreza Mesri. Soil Mechanics in Engineering Practice. New York, 1995. $550 \mathrm{p}$.

6. Б. И. Долматов. Механика грунтов, основания и фундаменты. М.: Стройиздат, 1981. 320 c.

7. V. Kazakauskas. Lietuvos limnoglacialinio molio paplitimas, sudètis, sedimentacijos sąlygos. Daktaro disertacijos santrauka / Geologijos institutas. Vilnius, 2000. 27 p.

Iteikta 20001109

\section{THE INFLUENCE OF NATURAL HUMIDITY UPON THE INDEX OF THE COMPRESSION OF LIMNOGLACIAL CLAY}

\section{A. Alikonis}

\section{Summary}

The coefficients of soil porosity and compressibility are not the only indices showing links between loading and squeezability. The index of compressibility is sometimes inconvenient for practical use. The graph of soil compressibility in the system of semi-logarithmic co-ordinations is a straight line, that's why the index of compressibility which is determined by it is a constant quantity and can be applied for a big interval of loading. The index of compressibility is very often defined as the interval the beginning of which is relictic pressure and is used to calculate the deformations of the soil layer when the loadings are bigger $[2,3]$.

The index of compressibility is different not only for different types of soil but for the same type of soil too, depending on the indices of its condition, its mineral composition and the peculiarities of its formation.

The author of this article has investigated the influence of natural and fluid humidity upon the compression coefficient of Lithuanian limnoglacial clays. The natural soil humidity was defined according to the standard method as the ratio of water mass which is in soil and the mass of solid particles.

Lithuanian limnoglacial clay from Jūros-Šešupès, KaunoKaišiadorių, Mũšos and Dysnos main basins was used for investigations. The plasticity index of solid soils was bigger than 17 , water saturation level was $0.8-1$. Hydro-mica (average $65-75 \%$ ) and kaolin (average 10-20\%) composed the mineral structure of limnoglacial clay.

The index of compressibility was calculated by working up the results of investigations. Most often the calculable interval was between the tensions $\sigma=0.2 \mathrm{Mpa}$ and $\sigma=0.4 \mathrm{Mpa}$. The calculated index of compressibility $C_{c}$ is connected with the natural humidity $\mathrm{W}$ of that soil. The values of coefficient $\mathrm{k}$ were calculated according to humidity and the compressibility index. A formula to calculate the index of compressibility was obtained.

The values of natural humidity $\mathrm{W}$ of solid soil varied from 10 up to $39 \%$, the values of the calculated index of compressibility $C_{c}$ from 0.13 up to 0.24 , and the values of coefficient $\mathrm{k}$ varied from 0.0033 up to 0.0066 .

Antanas ALIKONIS. Doctor Habil, Professor. Dept of Geotechnics. Vilnius Gediminas Technical University. Saulétekio al. 11, LT-2040 Vilnius, Lithuania. E-mail: vincentas.stragys@st.vtu.lt

Doctor (1968, technical sciences), Associate Professor at the Dept of Foundations Engineering. During 1980-96 Head of that Department (now Dept of Geotechnics). Research visits to Moscow and Dnepropetrovsk.

Author and co-author of 3 monographs, over 100 scientific articles, 2 patents, 5 inventions and 14 study guides. Research interests: physical and mechanical properties of soils. 